\title{
DRUGS COURT OF NEW SOUTH WALES AT PARRAMATTA
}

\author{
His Honour Judge David Smyth \\ INTRODUCTION
}

The irony was not missed on at least one of the members of the interviewing panel of the Winston Churchill Memorial Trust. Could it be that one of those countries whose forefathers had been sent to Botany Bay could learn from the penal experience of New South Wales? ${ }^{1}$

It was on January $26^{\text {th }}, 1788$ that Captain Philip and the First British Fleet held an official ceremony founding the British Colony at Port Jackson in New Holland. It had only been 18 years before, in 1770, that Captain Cook had landed at Botany Bay on his trip of exploration up the East coast of Terra Australis or New Holland and, whilst the idea of penal colonies was probably not unique to the British at the end of the eighteenth century, it is now hard to conceive just how audacious and innovative this social and geopolitical experiment was. The fleet which arrived and entered one of the World's greatest natural harbours in Sydney Cove comprised soldiers, freemen and convicts. ${ }^{2}$

Those who landed did not know how far west the land that they called New South Wales extended. They also suspected, erroneously, that New Holland was divided by a stretch of water from the Gulf of Carpentaria to the north to the Pacific in the south, called Williamson's Strait. Until the start of the $19^{\text {th }}$ Century little attempt had been made by Western explorers to circumnavigate Australia. Charts were virtually nonexistent. That this was audacious is beyond doubt. That it also had a huge influence on the future of the continent is now also certain. At the time it was not at all certain that this would succeed. Convict labour, cruelly treated even by contemporary standards, created roads, built buildings and carved out pastures in the swampy fields of this enclave, which was some three months by sea from the British Isles. It must have been "a strange Kafkaesque world, run by the notorious and corrupt Rum Corps." 3

The idea for this social experiment with its strong geo-political overtones may actually have initially been French but, whatever its genesis, the equivalent of today's Lord Chancellor's Department lost little time in marrying two ideas. Penal reform and colonisation. Deportation, often for offences regarded nowadays as being less serious, is a cruel and inhumane penal tool. Though it has to be remembered that transportation to Australia (as it was to become commonly known some years later) was looked upon as

1 This article resulted from a Fellowship from the Winston Churchill Memorial Trust to study the pilot Drugs Court of New South Wales in 2002. I gratefully acknowledge the assistance given to me by the Trust.

2 There are many accounts of the initial founding of the colony but I am greatly indebted and also greatly enjoyed Klaus Toft's, The Navigators which is an account of the initial efforts to circumnavigate and chart Australia.

3 Above, p 8. 
a lesser sentence than what so often was the alternative, death by hanging. ${ }^{4}$ Presumably, this social experiment found its basis in the initiative of Government and in Statute.

Now, only 214 years since the arrival of the First Fleet in what was to become Sydney Harbour, Australia, and Sydney in particular, is a multicultural society. Of its population of just under 20 million over 4 million live in the area of greater Sydney and, of these, 1.4 million live in Western Sydney with their health looked after by three Health Boards. It is in this area, in Parramatta, that the New South Wales Government began its pilot Drugs Court in 1999 with its basis firmly in statute, the Drugs Court Act 1998. In this sense, as in many others, this pilot project differs from the multiplicity of Drugs Courts elsewhere including those being piloted in the British Isles (in Wakefield, Dublin and, now, in Glasgow).

It was my intention to complete a study of the concept of the Drugs Court, compare the court at Paramatta with those examples in the United Kingdom and, if possible, relate this to our own experience locally in Northern Ireland. This was too ambitious. Others had already assessed the concept of the Drugs Court. The extent of my ignorance, both of the pharmacological and social effects of different illicit drugs and of the treatment regimes and resources available, was considerable. I now know more but it is still not enough.

The scope and the variety of Drugs Courts (there are now approximately 900 operating in the United States alone) and the extent and the breadth of the issues involved are so considerable that I am satisfied my initial objective had to be scaled down. The issues range through all those aspects of criminal justice, including both the principles of sentencing and procedural matters. Also, since what underpins the concept of the Drugs Court is the idea of therapy or treatment under some element of coercion, the issues cover the interests of health clinicians and all those involved in the health system. Finally, and most importantly, what are at stake are the safety of the community and the health of the individual.

The American Drugs Courts are now not only well established but they have been hailed by their proponents as constituting a revolution in criminal justice. The concept originating in Florida really encompasses "court supervised treatment" but with a twist. It attempts to marry treatment and coercion and to link health and justice in a unique way. The advocates of Drugs Courts claim that they "constitute a new kind of community (judges, prosecutors and defence attorneys, supervision and correction officers, treatment and rehabilitation providers) to restore our cities and our people to health." Essential to the operation of this "stick and carrot" approach is the central role of the judge as arbitrator, facilitator and mentor. The Australian variation in New South Wales has, however, its differences.

4 On the $11^{\text {th }}$ June 1800 Mary West had, with her mother, faced a committal hearing. She was charged with the theft of 46 yards of calico prints worth $\$ 25$. Aged 14, unrepresented, she was convicted and sentenced to death by hanging. Her sentence was commuted to transportation and she was sent to port Jackson. Nadine Wilson, The Adelaide Advertiser, June $23^{\text {rd }} 2001$.

5 Judge Jeffrey Tauber, Director of the National Drugs Court Institute. 
I have attempted to achieve a less ambitious objective in this article than a study of the concept of the Drugs Court. I am also only too aware of the fact that this may contain errors and inadequacies. I hope however that whatever its inadequacies it may lead others to directions in which their own researches determine whether the concept of a Drugs Court and this linking of therapeutic services with those of criminal justice have any relevance for the future of health and of sentencing in Northern Ireland.

I have divided what follows into four sections. The first is a description of the history and structure of the pilot New South Wales Court at Parramatta. It includes an account as to how it appears to an outside judge who has spent some four weeks observing it in action and an overview of the evaluations carried out on behalf of the Government of New South Wales together with some of the perceptions of those most closely involved in the operation of the court. The second section considers the Drug Courts currently being piloted in Glasgow and Dublin. The third section is an inadequate attempt to describe the present situation in Northern Ireland. It will be inadequate for a number of reasons; the scope of the subject, the lack of relevant research coming to my attention (in what is a small jurisdiction) and also the fact that the local drugs "scene" is constantly changing. This requires a degree of knowledge that is beyond my capacity. I have therefore tended to confine myself to what is very much an overview of one particular aspect of illicit local drug culture i.e. the abuse of opiates, a class A drug, and our response to it.

Finally, I give some of my own very general conclusions. I do so cautiously. One of the dangers faced by any judge is that, perhaps because of the nature of his job which can require him to assimilate things about which he knows very little, he falls into the trap of assuming that he knows more than he does and that he dabbles where he perhaps should not. This I hope to avoid.

\section{The Drugs Court of New South Wales at Parramatta.}

Parramatta, a city in its own right, is west of Sydney. It was one of the first settlements made outside Port Jackson and its history closely succeeds that of the first settlers. The courthouse, where the Drugs Court is located, is Parramatta's third. The tower of the second courthouse with its familiar crest of "Dieu et mon Droit" is incorporated into the functional, modern designed courthouse. The wall of the first can still be seen just across the road. A building housing a nursing museum dates from 1826 also faces it. I suppose Parramatta has something of the relationship which, for example, Lisburn has to Belfast. Parramatta is bigger and the social problems of the surrounding area, one of considerable urban sprawl, are greater. It lies on the route of the Great Western Highway, which, originally and literally, was hewn out by conscript convicts, often at the cost of their lives.

The Drugs Court has been allocated one of the medium sized courts and is recognizably similar to a UK or Irish court. It has however an area where the participant speaks which is not the witness box and which has a microphone. Everyone in court can see and hear what is going on and, as will be seen, that is an important part of the process.

The Drugs Court Act 1998 (referred to as the Act) and the Drug Court Regulations 1999 took effect on 5 February 1999 with the first matter being 
heard on 9 February 1999. The Drugs Court of New South Wales has the criminal jurisdiction of the District (our Crown Court) and Local Courts (our Magistrates Court) vested in it by the Act, which is not bound by the rules of evidence. ${ }^{6}$ For much of this description of the Drugs Court of NSW I am grateful to its first judge, Her Honour Judge Gay Murrell QC, who retired as the senior Drugs Court judge in 2002 and to her successor, Judge Milson.?

It is sufficient for immediate purposes to state, very simply, the nature of the concept underlying the Drugs Court of New South Wales. Its genesis was in the Drugs Courts originating in the United States but it has a very local flavour. As in America the court represents a partnership between the criminal justice system and the health system in which criminal justice plays a major, and probably the major, role. It accepts that drug dependency is a treatable condition. It also accepts that treatment, and consequently public safety, can be advanced under court supervision and coercion. Both these concepts are not free from controversy. ${ }^{8}$

The objectives of the Court are enshrined in the Act. It is to reduce the level of criminal activity that results from drug dependency. The Act has been amended by the Drugs Court Amendment Act 2002. These amendments are the result of the fruits of three years' operation and some are of considerable importance. To the objectives of reducing drug dependency (a health aim) and thereby reduce the level of drug-related offending (a criminal justice aim) has been added a further objective of promoting the re-integration of such drug dependant persons into the community (a social aim that, despite its nebulous quality, allows the Court to seek to achieve a wider object that will have both health and criminal justice benefits). ${ }^{9}$ The resolution of drug dependency, which is, obviously, a health problem, is the means by which the end of reducing offending is to be achieved.

Originally the Act restricted those eligible to non-violent offenders. This has now been modified and the Court now has a discretion that would allow certain offenders charged with "violent" offences to be eligible. ${ }^{10}$ Given that New South Wales is currently going through what appears to be an attempt to impose minimum sentences for a wide variety of offences this seems clearly to be a recognition by the Executive of the possible benefits to the community of such an extension of the powers of the court. With this

6 (s 24(1) and s 26(3).

7 I am entirely in the debt of Judge Murrell and Judge Milson for the friendship, hospitality and assistance they provided me. It is not easy for a judge to sit with a colleague on his left hand side as Judge Milson did for four weeks. I simply record here my thanks to them and to the many others who not only made my work easier but had already done much of it and who are clearly so committed to what they are doing.

8 For a comprehensive treatment of Drugs Courts including the concept of therapeutic Jurisprudence see Hora, Schma and Rosenthal, Notre Dame Law Review 1999 (74/2). For a devastating, if polemic, critique of these concepts I am indebted to Judge Hoffman of the Denver District Court, Colorado.

9 S 3(1) as amended.

$10 \mathrm{~S} \mathrm{7(2)(b)} \mathrm{"that,} \mathrm{on} \mathrm{the} \mathrm{balance} \mathrm{of} \mathrm{probabilities} \mathrm{and} \mathrm{having} \mathrm{regard} \mathrm{to} \mathrm{the} \mathrm{matters}$ referred to is subsection (2A), any propensity to violence that the person may have would not pose an unacceptable risk to the community or treatment providers if the person were at liberty to participate in a program under this Act. . "”. 
scheme Local Courts and District Courts in Greater Western Sydney ${ }^{11}$ must refer willing and eligible offenders to the Drugs Court. Eligibility is determined once an offender pleads guilty, is "highly likely" to receive a sentence of actual imprisonment, is assessed as dependant on illicit drugs and is a person in respect of whom a suitable program and facilities exist. Subject to the recent amendment violent and sexual offenders are excluded from participation. ${ }^{12}$ Potential success on a Drug Court program is not an eligibility criterion. However, the policy of the Court, which must have a "treatment plan", is that the Drug Court team will support a treatment plan only if it considers that plan as "suitable". This gives some scope to exclude prospective participants whose prospects of success are very low.

Participation in the program can be terminated if the Court is of the view that "no useful purpose" will be served by the offender continuing to participate. Interestingly there is no appeal against the determination of the Court in this regard. The decision is also to be made on "the balance of probabilities". Substantial amendments have now been made to those sections dealing with termination. These had not come into effect when I last viewed a "no useful purpose" hearing in 2002 but such a hearing reverts to the greater formality and more obvious adversarial quality of a court. ${ }^{13}$

The Court is very much a last stop. It is not diversionary in any sense, unlike some programs based on restorative justice and other disposals outside the court system. There are also other, less intensely supervised, systems that deal with drug addicted offenders such as the merit system operated in Melbourne, Victoria. Here in New South Wales, typically, offenders have a substantial criminal record, are referred for several offences of dishonesty (to the offences of burglary, receiving, taking and driving away and theft are

11 The catchment population is approximately 1.4 million, covered by three health boards and having a strongly urban and commuter base.

12 That NSW has a serious opiate problem is not in doubt. The doubts arise as to how that problem should be best dealt with. I give here some figures that can be contrasted with what (limited) figures appear later in this article in relation to Northern Ireland. In 1998 it was estimated that 24,000 people in NSW had used heroin in the preceding 12 months (NSW Bureau of Crime Statistic; Progress of the National Drug Strategy). The Bureau advises that burglars using heroin commit a median of 13 burglaries a month, generating a weekly income of $\$ 3,000$ (The Stolen Goods Market in NSW, BOCSAR 1998, Stevenson and Forsyth.).

The NSW Department of Corrections estimates that $60 \%$ of the male intake into prison receives medication for drug or alcohol withdrawal. It is estimated that in any one year $40 \%$ of injecting drug users pass through prison. Up to $80 \%$ of the inmate population is received into custody in relation to drug related matters (including alcohol) (Dept Of Correctional Services 1997-1998 Annual Report). The figure for women is expected to be higher. In a recent reply to a NSW Parliamentary estimates question, Michael Richards, the Corrections minister, indicated that the figure of those receiving treatment for withdrawal in prison was rising steadily and each year. Those leaving treatment had also largely left prison.

13 Sections 10 and 11 cover the imposing of sanctions and terminating. "No useful purpose" has been replaced by "unlikely to make any further progress" and "further participation on the program poses an unacceptable risk to the community that the offender will re-offend". Because of a perception that the original wording of the Act had set too high a standard "successfully completes the program" has been replaced by "has substantially complied with the program". 
now likely to added some offences of robbery involving minimal violence) and are likely to have a history of heroin dependency.

The abuse of both amphetamine and benzodiazepam is also present as is cannabis and some ecstasy but these drugs are more to be encountered in combination with opiates. There are other ways of dealing with the problems presented by the abuse of "recreational" drugs like ecstasy and cannabis. The profile of a typical offender will include social, personality, mental health and educational problems. Many have been known to the welfare and health services for some time. A surprising number, however, present all or some of these problems and have been picked up by the relevant agencies for the first time in the Drugs Court.

If a "suitable" treatment programme can be devised for an eligible offender, the Court passes an initial sentence, which is one of imprisonment, and it suspends operation of the sentence for the duration of the offender's Drug Court program. Initially, since most offenders come to the Court in custody, the Court remands the offender for two weeks to detoxify and for the preparation of the appropriate reports in the remand centre at Silverwater Prison, Auburn. ${ }^{14}$ The connection between custody, detoxification and the "crisis point" which this creates in an offender's life therefore appears crucial to this type of intervention. Every Drug Court program involves treatment for drug dependency (counselling, and, most frequently, the prescription of alternative drugs such as methadone, naltrexone and buprenorphine).

An offender once accepted into the programme can self-terminate at any time. Participation is therefore voluntary at all stages. Since there are concerns in relation to the manner of imposition of sanctions, the subrogation of the rules of evidence and to both a judge and defence advocate, but not the offender, being present at a "case conference" consent is seen as being vitally important.

The offender has a counsellor (health) and there is an assigned case manager to the offender who is a probation officer. Emphasis is clearly therapeutic and assistance can be made with accommodation, education and employment through the Probation and Parole Service whose staff appear to take a robust view of their duties.

However, central to the whole concept of the Court and its theme of therapeutic intervention and treatment under a form of coercion, are regular, supervised, urinalysis and regular reporting back to the court. The NSW Drugs Court, whilst it follows the example of those courts in America, is developing its own ethos, less based on zero-tolerance or total abstinence. In part this is because it deals with the most intractable problem of illicit drug abuse- those who are problem heroin users. It is therefore a pilot scheme that

14 This has a drugs free wing that is not wholly dedicated to those on remand to the Drugs Court. Nursing and health care staff this along with correctional Department employees (our Prison warders). It has to house other inmates and, although both staff are dedicated and the wing is drug free, conditions are far from ideal. Women are remanded to Malawa, the women's correctional facility, which I did not visit but anecdotal accounts suggest that conditions are poor. There is certainly little opportunity to do anything other than "dry out" offenders at Silverwater. 
is both based on statute and is highly focused on opiate abuse. It does not rely to the same extent on the involvement of communities as the Drugs Courts in the United States and has, to a certain extent, refined for itself the 10 key components of Drugs Courts which have been established by the American system. ${ }^{15}$

The Court sits at Parramatta, where its registry takes most of the supervised urine samples. ${ }^{16}$ It sits Monday to Thursday with Friday being used for a review meeting on overall progress and policy. Two judges have been appointed. Consistency of judge (and indeed consistency of approach by that judge) is all-important. The Court accepts referrals from District and Local Courts in greater western Sydney (Auburn, Cambpelltown and Penrith). When an offender is charged before a District Court or Local Court with an offence, it is the duty of that court to ascertain whether the offender appears to be an "eligible person" and whether the offender is willing to be referred to the Drugs Court to be dealt with for the offence. ${ }^{17}$ If so, the District or Local Court must refer the person to the Drugs Court. Unlike Glasgow and Dublin, where there has been a slow take up, the pilot Drugs Court of NSW has had no difficulty in getting referrals. The places are limited.

Two things seem reasonably clear. The first is that since the offender is "highly likely" to receive a prison sentence in the referring court he has an incentive to consent. The second is that it may well appear to an offender that participation on a Drugs Court program may be a less onerous option than imprisonment. It also has to be recognised that the pool from which eligible offenders are likely to come will include amongst its number a reasonable proportion who either think the system can be manipulated or who would wish to put off the evil day. The degree of supervision (which comes essentially from four angles; court, counsellor, case Manager and

15 National Association of Drugs Courts adopted by the UN International Drug Control Program Expert Working Group, Vienna, December 1999. These are the integration of treatment into the criminal justice system; prosecution and defence lawyers work together as part of a Drugs Court team; participants have access to a continuum of quality treatment and rehabilitation services which meet their health needs; participants are frequently monitored for drug use; any non-compliance by a participant results in a swift and certain sanction by the court; there is ongoing judicial supervision and regular judicial interaction with each participant; there is evaluation of the rehabilitation outcomes achieved through the drug court; the team and others associated with the court receive ongoing inter-disciplinary education; networks are forged with other Drugs Courts, law enforcement authorities , public bodies, treatment providers and the community.

16 The Court Registrar, John Castellan, has constantly improved and improvised on a system for taking such samples, a necessary part of the whole concept of the Drugs Court. Since the first court was established in 1989 in Dade County, Florida there is now a considerable literature devoted to the way in which such samples should be taken, a compromise between reducing scope for fraud with as little impact as possible on dignity. There is also an illicit literature based mainly on the internet which centres on how both to give false samples and to obtain the means of doing so. The program participants visit the registry by means of an entrance at the rear of the Courthouse. This means they avoid going through the atrium of the courts but also means that they share an entrance used by the jury panel.

17 S 6. 
urinalysis) is sufficiently close and intensive that manipulation is, in the long term, difficult. The price usually is paid in terms of failure, termination and in final sentence.

Initial referral is by telephone. When a referring court makes a telephone inquiry of the Court registry, the Drugs Court team checks for outstanding charges in order to avoid the unnecessary transfer of an offender who is not an eligible person. If the offender appears to be eligible, the matter is listed before the Court the next day if there is room in the list. The program can take many months. Prior ${ }^{18}$ to an offender's first appearance the Nurse Manager on the Drugs Court team arranges a preliminary assessment of the offender's drug dependency. Each offender who does not have private representation consults the legal aid solicitor attached to the Drugs Court team and is advised about the Court's programs and the option of returning (at any stage) to the referring court to be sentenced in the usual way.

The accommodation of offenders is restricted. At the remand centre, MRRC, Silverwater (for men) ${ }^{19}$ the Court has six beds dedicated for occupation by offenders who, following their first appearance before the Court, opt to pursue their application for admission to a Drugs Court program and undergo detoxification and comprehensive assessment in the prison hospital over a period of one to two weeks. For women two beds are available at Mulawa Correctional Centre. Following this period the offender returns to the Drugs Court and, if a suitable treatment program is available for the offender and he accepts the conditions of his proposed court program, then the Court proceeds to formally convict and pass the initial sentence. A plea in mitigation is heard. This is a formal hearing and, like all appearances before the Court, is taped. Both police or prosecuting lawyer and defence are heard. The sentence is suspended for the duration of the Drugs Court program and, upon sentencing of the offender, the Court imposes the conditions which constitute the offender's Drug Court program.

A program lasts, on average, about 14 months. It falls into three phases with the first naturally involving the closest supervision and scrutiny. Phase one, where the average time spent is three months, is a stabilisation period. It involves urinalysis at least twice a week, most frequently three times at the start. It also involves attendance at the Court twice or at least once a week. Once it is realised that the judge rarely changes and that a close inquiry is made of progress, regression and major relevant events by this judge of the participant the difference between this Court and a court as the Common Law would understand it becomes obvious. The second, consolidation, phase again lasts on average three months. Attendance at Court would,

18 The NSW system of Legal Aid depends on salaried lawyers. Advocates are solicitors who are assigned specifically to the Court by the Legal Aid Department. As such they are clearly familiar with the workings of the Court and are in agreement with its ethos, which is largely non-adversarial since the object is therapeutic for the offender. It has to be recognised though that there is a possibility of this system operating somewhat differently if lawyers were paid a fee for individual items of work. There is some literature elsewhere about the risks of "strategic billing" but that is a different subject!

19 For all of this I must acknowledge my indebtedness to Her Honour Judge Gay Murrell, without whose assistance and papers this would have been impossible to complete. 
typically, be once a fortnight. Urinalysis is done twice a week. The final, reintegration, phase sees the frequency of court attendance drop to once a month and also sees the frequency of urinalysis drop.

It is hard to convey here, particularly to Common Lawyers used to adversarial and to formal courts, the extent of the differences that exist and also the culture shock that a visit to such a court entails. Certain aspects have been directly imported from the American experience where the enthusiasm for the benefits of the Drugs Court concept is almost evangelical. A judge is not a social worker. That sentiment has been expressed and is one with which I agree. That is not the nature of our job. Do Drugs Courts and judges play this central role because of the intractability of the problems and because other agencies whose job is health and welfare find it difficult to cooperate in an effective way together? Do the merits of this system depend in part upon the novelty of a judge playing this role? Is this why this system has become so popular, the existence of a form of coercion both on the agencies and upon the subject?

For four weeks I observed the Drugs Court at Parramatta. I sat though case conferences where (in his absence) the history of an offender appearing that day in court was discussed. I also sat and listened to the direct dialogue with the judge as each person approached the microphone. My experience did not prepare me for the first occasion when applause broke out in court. The system not only operates on the imposition and immediacy of sanctions but also of rewards. Upon graduation from phase to phase, upon final successful termination and even just where someone has done well against the odds, (like the first clean weekend) applause is used. Describing it thus suggests there is something of the Oprah Winfrey Show about it. The role of public applause in both reinforcing and also in rewarding the individual is seen as vital by the court psychiatrist, Dr Paul Read. It is seen and is participated in by all in court. Those who have done well are taken first. Continued progress is rewarded by the removal or remission of sanctions.

The progress of participants is monitored by the judge of the Drug Court and by the Drug Court team which consists of prosecution and defence solicitors (usually legal aid salaried advocates), a police inspector, a senior nurse manager who coordinates health and a probation officer (all assigned to the Court). There is a "case conference" which precedes the open hearing of the Court and which lasts from 9.30am until 11.00am. Needless to say it is always under pressure of time. Lists may be as long as 45 , including some matters for initial appearance, some for initiation unto the program and first sentence, some for "no useful purpose" hearings and the reporting back of participants. Each of these cases is considered at the case meeting. Brief reports are led by the health coordinator and by the probation officer as to progress and any developments. The Clerk to the Court (who, interestingly, is, in New South Wales, assigned to the judge as his associate and not to the court) reads out the urinalysis reports from the Court Registry. The absence of the accused (despite the presence of a salaried lawyer acting on his behalf) and the presence of the judge who not only presides but also discusses his attitude with the other participants is, for Common Lawyers, something of a 
shock. Information is shared, opinions are offered and any appropriate sanction or reward is openly discussed, all under pressure of time. ${ }^{20}$

At the hearing the offender reporting back comes forward as soon as his name is called. He is aware that the judge already knows something about his or her progress over the intervening period (which, typically, can vary from two days to a month). After this discussion, which is informal and which is listened to intently by all those in Court, the Court may administer sanctions (up to fourteen days' imprisonment) or confer rewards. These include the remission of "suspended" sanctions of imprisonment. Recently the Court had established a new policy as regards the sanction to be imposed for the use of an illicit drug. ${ }^{21}$ A drug use, if admitted promptly, was treated less seriously. Since the Court is not bound by the rules of evidence it may inform itself in any way it considers appropriate. Its decisions on these matters are not the subject of any appeal to another court. ${ }^{22}$

The treatment available, both in terms of medication, availability of courses and of residences, is from our perspective in Northern Ireland both generous and varied - at least in Northern Ireland health terms. ${ }^{23}$ There are available at least 13 hostel or residential homes, many religious based. The five main treatment streams are; residential based abstinence, community based abstinence, substitute prescribing (methadone naltrexone and bupanorphrine, residential or community based). ${ }^{24}$ The participant, if based in the community, receives two home visits a week and support services are provided in the form of assistance with housing, life skills, vocational training, employment, family support and literacy skills. Many participants

20 Behaviour which gives rise to sanctions includes: testing positive for a prohibited drug (alcohol can be expressly ordered by the court to the list), failing to provide a urine sample, failing to punctually attend a court sitting or a counselling appointment without reasonable excuse. Different courts have different approaches to the use of sanctions and some are used more widely than others. Judge Milson swiftly imposed custodial days that could be suspended to a stage that required them to be served. Not only did this tend to encourage compliance, it also permitted the use of remission of some or all of these days as a reward.

21 A drug use admitted speedily to the appropriate counsellor, case manager and to the Registry would receive a day's sanction in custody. An unadmitted use would receive three days. The object is to encourage honesty.

22 Though I suppose in a litigious society where legal aid is available there is always scope for judicial review. It does not appear to have happened.

23 The process by which a participant is placed on a treatment plan is governed by the Court's treatment plan policy, which has been constantly refined as a result of the experience over the past three years and is also available, along with much other useful information, on the Court's website, <www.lawlink.nsw.gov.au/ drugscrt>.

24 Naltrexone is an opiate antagonist that blocks the craving for heroin. I believe it also has been used to treat alcoholism. Surprisingly, according to Judge Murrell, $40 \%$ of offenders entering a Drug Court program have had no significant prior treatment. According to the present Drugs Court Judge, Neil Milson, a very high proportion of offenders have thrown up mental health and literacy problems that have neither been treated nor properly addressed. By the Drugs Court Regulations 1999 a person is not eligible if "suffering from any mental condition that could prevent or restrict the person's active participation in a program under the Act". Reg 5(b). What mischief this was aimed at preventing is not entirely clear but it is interpreted in a way that has provided no problems. 
either completed their schooling in the juvenile justice system or left school at the first opportunity without visible benefit. It is this failure, if failure it is, on the part of the educational system and other responsible agencies that could possibly lie at the heart of the Drugs Court concept. At a very late stage, and in court, all these agencies are at last required to work (effectively?) together under the structure of an Act of Parliament and supervised by a judge.

A Drugs Court program lasts a minimum of twelve months. Unsuccessful participation results in termination and the imposition of a final sentence, which is usually a sentence of a significant length in prison but which cannot exceed the initial sentence imposed by the Drugs Court on admission to the program. Successful participation results in graduation from the Drugs Court program (this, and progression from each phase, is rewarded by a certificate) and the imposition of a final sentence, usually a good behaviour bond. ${ }^{25}$

The typical profile of a participant has been subject to research by the NSW Bureau of Criminal Statistics and Research (BOCSAR). He, generally, will be male $(85 \%)$, be referred for 7 offences, mostly of dishonesty, face on average a sentence of 9-10 months imprisonment, ${ }^{26}$ and be heroin dependent $(83 \%)$. His dependency is likely to have commenced in his teens (which appears to be earlier than available data suggest to be the case in Northern Ireland) and he certainly will have been to prison before. He is also likely to have a background which includes a background of parental drug or alcohol abuse, family conflict, childhood abuse and, of particular relevance in Sydney, refugee dislocation. He is likely to still be young $(50 \%$ are aged between 18 and 25) and, (and this is, perhaps surprising) to have had little by way of prior treatment.

\section{The Role of the Judge and of the Team.}

Earlier in this article I described the "culture shock" that a visit to the court induced in a Common Lawyer accustomed to the adversarial approach of an ordinary criminal court. It certainly is clear that the Drugs Court concept generally and the Drugs Court at Parramatta in particular represent a new direction within the traditional Common Law system, both in formal structure and in the approach to sentencing. It is not concerned with findings of guilt since offenders will all have pleaded guilty but there are occasions on which the Court has to make findings and apply rules to facts that are in dispute.

25 Diversion schemes which seek to achieve the rehabilitation of drug dependent offenders by diverting them into treatment are by no means new and there are many and varied examples. The attachment of "fourth conditions" on Probation Orders made by the Court under the Criminal Justice Order (NI) 1996 requiring the offender to take treatment, the deferral of sentence by a court to allow an offender time to embark on treatment which he says he needs is used in Northern Ireland and Scotland. The "Griffith's remand" (adjourning a matter to allow treatment to take place) has now been formalised in NSW by section 11 of the Crimes (Sentencing Procedure) Act 1999 (NSW). Bail diversion schemes exist in many jurisdictions and form a large part of the basis for those examples of Drugs Courts in the British Isles.

26 Though the cases I observed all had initial sentences imposed that were well in excess of these figures. 
For example "no useful purpose" hearings can be contentious matters upon which the judge has to exercise his powers of judgement. There also are frequent occasions when facts are disputed. An example is when a participant disputes what appears to be the result of a laboratory test of his urine. The court applies a test based on the balance of probabilities. A judge has to make quick and accurate decisions that may be informed by urinalysis results, the participant's physical appearance, opinions (given in court) of the health manager and probation coordinator, and the reports of treatment providers and case managers. What the participant says in court and his responses to direct, and often confrontational, questions put, not by the prosecution but by the judge, also inform this decision. In the view of Judge Murrell there is little scope for mistake. Drug Court participants are highly practised in deception, having honed their skills on family and friends over the years. However, she concedes that on occasions there is scope for uncertainty and that mistakes no doubt have occurred. It is her view that the need for quick and fair decisions on program breaches is paramount and that participants are quite capable of understanding, and of accepting what underlies a decision made "on the balance of probabilities".

What makes for this difference? Is it beneficial? The judge has a central and pivotal role in this system. There is a real case to be made that this structure has grown up in its various different forms because of the failures of other agencies to target intractable problems at a sufficiently early stage. These problems can be in welfare, housing, education or mental health. Quite apart from the "working with" difficulties that all agencies seem to encounter there also is the reluctance, real or apparent, on the part of the patient/client to seek out help or to be motivated to be helped. By whatever route the offender arrives in the court is it proper to regard his addiction as a treatable disease? If the answer to this is yes, then is it a short step to link the possibility of a reduction in offending with the rehabilitation of the offender? That is easier to state than to achieve and it also begs the question of individual responsibility. One of the notable aspects of all these schemes is that mental illness excludes participation.

There are difficult matters of medical and legal ethics and also of private rights. A court of law should not be a court of morals. Nor is a judge a social or a health worker. Likewise a clinician does not want to be a policeman. Yet, to some extent once the disease model of drug dependency capable of treatment is accepted, as it now appears to be, both by health professionals and by lawyers involved in the Drug Court concept, a complex mix of elements is unavoidable. The former presiding judge of the New South Wales Court, Her Honour Judge Murrell QC, said:

"The moral component is particularly significant because the Court deals with offenders whose drug dependency has led to criminal behaviour. Such behaviour has a social impact and cost extending well beyond the offender's personal and domestic situation. The requirement that drug dependent offenders accept personal responsibility for their behaviour and its social consequences and maintain accountability to the 
criminal justice system is at the core of case management of participants by the Drug Court." 27

The theory is that the Drug Court participant comes before the court at a real crisis in his or her life. It may well be that they have been to prison before and accept that as being inevitable. Prison has not discouraged them so far from committing offences and neither has it encouraged them to benefit from treatment. They, however, still face significant incarceration with all the cost to themselves and to their families which that entails. It is this crisis in their lives which may provide an impetus for potential change. The question is whether the court can capitalise on that possibility for change, and if so to what extent? ${ }^{28}$

Because of the nature of the Court and the belief that addiction is both capable of being treated and that this can be encouraged by supervision and by a degree of coercion, the normal adversarial nature of a court sentencing an offender is altered. To some extent rehabilitation displaces punishment and deterrence. This alters fundamentally the perception of the prosecution (and police) on the one side and the defence on the other. Normally the prosecution would emphasise the objective facts which make the crime serious and the defence the offender's unfortunate subjective circumstances. The judge, normally, listens to both (with a minimum degree of intervention) and then decides on penalty having weighed up the competing aspects, punishment and deterrence emphasised by the prosecutor, rehabilitation emphasised by the defence.

Because of the stress on rehabilitation, and the importance in relation to that of the offender's personal circumstances, a remarkable consensus frequently emerges. This is not only encouraged by the objectives of the Court but also by very way in which those who comprise the team can address their work. It is comparatively rare that the case meeting held before the start of the public hearing in court does not reach a consensus on both what is happening and what should happen to an offender. Desirable outcomes seem to emerge. Everyone appears to be singing from the same hymn sheet. This meeting is presided over by the judge who, as team leader, clearly tries to achieve a consensus where possible. Although this meeting always appears to be under pressure of time it makes what happens in court much shorter.

Given the nature of the role assumed by the judge who presides over a Drugs Court there are demands made of him that are not normally expected of a conventionally trained and experienced judge. Apart from the extended

27 Her Honour Judge Murrell QC, Australian Law Reform Commission Journal, 2002. This personal acceptance no doubt underlies the recently introduced policy of the Court in imposing harsher sanctions for unadmitted use of illicit drugs than for admitted use. The need is not just to encourage and reward honesty to the Court but to oneself.

28 "Therapeutic Jurisprudence" is a term that, like so many other concepts in this area, originated in the US. It is an approach that acknowledges that, regardless of the outcome of legislation, the litigation process may be therapeutic or antitherapeutic. The court may choose to capitalise on the opportunity for change presented by this crisis in a litigant's life, or may unwittingly reinforce negative attitudes and anti-social conduct. Peggy F Hora and William G Schma, Judicature, (82) 1. 
nature of the work and the obvious need for consistency of handling of cases there are additional requirements for him or her both to lead the "case work" team and also to assume a role in court that is unique to any Common Law jurisdiction. This has wide implications, not least for the type of selection and training which could help to equip judges to play this role.

The Drugs Court team brings different disciplines together. It develops its own working ethos. The members meet every day. Initial antagonisms, largely due to a lack of knowledge and understanding, between health and law have disappeared. Both the prosecution and police members of the team on the one hand, and the salaried defence lawyers on the other, so clearly believe in what they want to achieve that, whatever their initial conceptions were, they can now be regarded as converts to the new structure.

When the New South Wales Drugs Court commenced, there were, according to Judge Murrell, frequent and significant differences of opinion between health professionals providing treatment to participants and the Drugs Court team. That seems to be a distant memory. There still are differences between the team and treatment providers but that could be expected and, in any event, some disagreement is healthy. The Court's approach is, as it has to be, that rehabilitation from drug dependency (and from associated criminal conduct) is ultimately an exercise of free will. I have referred to treatment "under coercion" but a participant is only in the Court because he has committed a crime. He may be there because that crime has been influenced by his drug dependency but it his offending which has put him there and for which he is accountable. Since he is also on the program because of his initial consent his participation is ultimately voluntary. He can walk away by self-terminating at any time.

\section{Does Treatment Under Coercion Work?}

This is a question to which we would all like to know the answer. If there is an answer I am quite satisfied we will not easily find it. Is an addiction to a drug a disease? If so, is that disease capable of being treated? Is treatment more likely to be successful if the patient is a free agent or under some form of compulsion? The evaluators of the NSW Drugs Court understandably avoided such a philosophical question. They, however, comprehensively evaluated the court in three separate studies. ${ }^{29}$

Perhaps of most interest, from the point of view of this article, is the study of cost-effectiveness. This assessed the cost of the scheme and its effectiveness in reducing recidivism amongst participants with the cost of conventional treatment (read imprisonment) and its effectiveness in reducing re-offending after release. Unlike many of the American studies the evaluators were able to use a randomised control group who had also been deemed eligible for the Drugs Court scheme but, due to a shortage of places, were sentenced to prison. ${ }^{30}$ It was this that perhaps made this evaluation uniquely valuable.

29 The New South Wales Drugs Court Evaluation: Cost-effectiveness: A Process Evaluation and Health, Well-being and Participant Satisfaction. All were published in February 2002. NSW Bureau of Crime Statistics and Research.

30 This study has what appears to be a comprehensive and valuable précis of previous research, pp 1-6. 
Despite the constraints imposed by the time period being studied some interesting conclusions emerged. While Drug Court participants had lower rates of offending than the members of the control group the differences were statistically significant only for a limited number of offences, namely those connected with drug use. However, when those whose participation in the Drugs Court scheme had been terminated were excluded from the equation, the lower rates of offending (whether measured in terms of "free time" to a first offence or by frequency of offending) became significant. This, in itself, does not point to very much beyond suggesting that for some the scheme appears to work well and, again for some, achieves its objective in reducing offending, and incidentally is as "cost effective" when set against traditional measures like imprisonment. In a way, that is to be expected. Where the scheme works it works well.

In relation to cost, the estimated cost per day of the scheme was not much less than that of prison and conventional disposals ( $\$ 144$ as opposed to \$151) and not really significant though there may have been longer-term benefits and savings that are difficult to assess.

Some measures were highlighted whch might improve the situation: the ability of the system to better identify those whose chances of success were more favourable, the earlier termination of those who were unresponsive and the relaxation of the stringent "graduation" criteria. The imposition of overfrequent custodial sentences resulting in a return to prison which disrupted treatment programmes was already being dealt with by the introduction of the idea of suspending sanctions (which could also be remitted). Whilst these would reduce costs they would not overall affect re-offending rates.

The picture was much brighter when other aspects were looked at. Strong support was found for improvements in health, social functioning, in wellbeing and in reduced drug use sustained over a twelve month follow up period. In particular illicit drug use was significantly reduced throughout participation on the programme. Median spending on drugs, used as a proxy measure for drug use, fell from $\$ 1,000$ a week to $\$ 175$ per week after four months on the programme. While there remain caveats about these matters the improvement was not only significant but was also maintained in an environment where participants were in the community and had access to those markets they were involved with prior to commencing the programme. ${ }^{31}$

There are so many issues involved. One of those of particular difficulty for those most closely concerned in the operation of Drugs Courts, lawyers and clinicians, is that the difference in our respective professional ethos makes us approach the issue in different ways. The doctor/patient relationship is bound to be different from that of litigant/lawyer or of the policeman/legislator. On a less "philosophical" note than whether treatment under coercion has advantages there are practical arguments from clinicians about the fast tracking of unrewarding patients by courts and probation, issues of confidentiality and problems as to who provides the funding. None of these problems are insuperable. A lot of them arise because of lack of

31 Op cit $\mathrm{p} 40$. 
understanding and ignorance. This is as much on the part of judges and those in the criminal justice system as it is amongst health workers.

A much more important problem is the clinical one, does treatment under coercion as opposed to free will work or, at least, has it advantages which are so significant that it is worth trying?

\section{Drugs Courts Glasgow}

This started in the Glasgow Sheriffs' Court in October 2001 and is quite a contrast to the Drugs Court in Parramatta. Like New South Wales it owes much to the American concept of Drugs Courts. ${ }^{32}$ Again like Parramatta, it has given a local flavour to the way in which and to the extent to which it has accommodated that concept. The inauguration of the Court in October 2001 followed the report of a working group established by the then deputy Minister for Justice in the Scottish Executive, Mr Iain Gray MSP. ${ }^{33}$ The brief of the group was not to study the feasibility of such a project in Glasgow but rather to have such a Court up and running in Glasgow by the autumn of 2001. It was therefore accepted that the concept was worth trying and this was an implementation group. The report drew heavily on the experience of Drugs Courts in America, Canada and Australia. It also considered what had been happening for some time in Wakefield and what was about to happen in Dublin, which was about to set up its own pilot.

The objectives of the Court (and what the Court will be evaluated upon) are threefold: the reduction of the level of drug related offending behaviour, the reduction or elimination of an offender's dependence upon drugs and the examination of the viability of a Drugs Court scheme in the rest of Scotland. Unlike the elaborate statutory authority of the enabling Act of the New South Wales Drugs Court ${ }^{34}$ the Glasgow pilot court has to demonstrate such viability "using existing legislation". It can however suggest "legislative and practical improvements which might be appropriate". Formal evaluation is to be completed at the end of 2003.

The scheme was simple and naturally reflects naturally the central role of the Procurator Fiscal in the Scottish criminal justice framework. Offenders admitted to the Court must be over 21. There has to be an established link between the offender's serious drug misuse and the offending behaviour. Mentally ill offenders are excluded from the scheme. The original system of referral was envisaged as being by an initial sift of cases by the Strathclyde Police with the Fiscal then screening and deciding which cases were suitable

32 See the Ten Principles of Drugs Courts at above.

33 Report of a Working Group for Piloting a Drug Court in Glasgow. Scottish Executive, $1^{\text {st }}$ May 2001. The 11 members of this group reflected its brief, which was very much court orientated. Of its member only one could be considered as coming from health (addictions). The rest were Shrieval, courts service and criminal justice. The nature of the group's brief and speed with which the court was set up may reflect the severity of the drug problems in Scotland's major cities, the link that has been established between that and acquisitive crime and the arrival of the relatively new Scottish Executive keen to do something about what was perceived as the "revolving door" of offenders spending frequent periods in prison with little or no reduction in their offending behaviour.

34 The Drugs Court Act 1998, as amended. 
for consideration. Admissions of guilt and consent are required. Social work and the views of the defence advocate are provided for. A screening group headed by the Fiscal and including police, social worker and the Defence Advocate would decide what cases should be referred to the Sheriff in the Drugs Court who would then remand on bail for four weeks for appropriate reports to be sought. ${ }^{35}$

Two Sheriffs staff the Court, which sits four days a week. Each Sheriff sits on alternate weeks in the Drugs Court and in the other week does other work. The pivotal role of the judge as the team leader is recognised. Cases are reviewed by a group, which is chaired by the judge, in the courtroom on the morning before the offender appears in court. This review group consists of the Fiscal, the social worker, the addictions counsellor and the Defence Advocate, if he appears. The offender is not present although reports, test results and views of his progress are considered. He appears in court in the afternoon and his views are canvassed but possible decisions may well have been discussed that morning. The same judge hears a case from its start to its conclusion. The Drugs Court team has accommodation close to the court where the urine tests are carried out.

The perceived benefits of frequent supervision and of monitoring behaviour are recognised by regular appearances in court ${ }^{36}$ and by the frequency of urine testing, which is done at the separate but adjacent building that houses the health teams. Some recognition is given to the importance of the imposition of sanctions and the issuing of rewards but this is limited by the restrictions inherent in the scheme and is also considerably circumscribed by the court being confined to the use of existing powers.

Unlike America, Paramatta and Dublin there is no "graduation" between different stages. Sanctions are extremely limited. They include increasing the frequency of appearances at court, the frequency of testing and of counselling. ${ }^{37}$ "Rewards" include praise given in court and the easing of these requirements. The "direct dialogue" between judge and offender is evident. In a quiet court where, although the public are admitted they rarely come, offenders see their own progress discussed and also that of others. Formal breach proceedings are provided for. These have occurred but on relatively few occasions and can result in the Order being terminated and in immediate sentence. The Drugs Court has the powers of a normal Sheriff's court.

An initial interim evaluation was carried out after six months. ${ }^{38}$ Clearly an evaluation carried out at this early stage has to be severely limited. Certain deductions could be made from statistics, from the evaluation of court records and from the perceptions of those involved. No helpful outcome results could be expected. This year a more detailed evaluation is anticipated

35 A target not always met despite this being regarded as a "fast tracking" process.

36 This varies from fortnightly appearances to monthly and so on.

37 This was one the recommendations made by Sheriffs to the evaluators. The Deputy Minister for Justice, Hugh Henry MSP, in the Scottish Assembly debate indicated that the Criminal Justice (Scotland) Bill will contain powers enabling the court to impose a range of interim sanctions.

38 The Glasgow Drugs Court: the First Six Months. Scottish Executive Social Research 2002. 
though even then its ability to assess outcomes will be limited by the time scale involved. A period of two years will tell something, though perhaps not a lot, about recidivism, the reduction of drug consumption and, perhaps of less prominence given the objectives of the pilot, of improvements in health and lifestyle.

Certain matters that are no doubt capable of being addressed were thrown up by this preliminary evaluation. The number of police referrals was well below the level expected, whether due to police ignorance of the scheme or to reluctance on their part to use it. The Sheriffs felt the lack of a more sophisticated system that enabled them to impose sanctions and rewards. Interestingly, given the increased degree of supervision and monitoring introduced by the scheme, they felt that a "mentoring" system would also have benefits. Otherwise the picture was one of the scheme working albeit at a lower take-up rate than had been anticipated. Sheriffs were understandably keen to increase numbers. Medical and social workers clearly felt the pressure of court demands and workloads. Sheriffs in particular felt they had benefited not just from the knowledge they acquired through hearings but from frequent, more comprehensive and more focused reports when ultimately sentencing offenders.

Pre-court reviews held in the absence of the offender and court reviews held in open court were felt by all participants to be beneficial although some "clients" expressed a desire to be present at the former.

At the very core of this scheme in Glasgow is substitute prescribing and, in particular, of methadone. This is of importance for anyone in Northern Ireland considering the merits of a Drugs Court system. The Drugs Court team and external providers deliver counselling, prescribing, access to day programmes and to primary medical care. Various issues were identified in this preliminary evaluation: issues of a medical nature (relating to the prescription of methadone), of the scope and nature of services provided and of both a practical and ethical nature in relation to urine testing. These were not, however, the kind of issues that would be difficult to tackle. ${ }^{39}$

Of more questionable value were the reports of reduced drug consumption and of a reduction in offending behaviour. Quite apart from the short time span involved two things make the value of any deductions about success based upon this questionable. These assessments were largely based upon self-reports, albeit backed up by drug tests. Secondly, the intensity of court supervision, counselling and monitoring by tests would provide a strong short-term incentive, no doubt at considerable cost, to both reduce consumption and avoid offending. However this is also the case in relation to Drug Treatment and Testing Orders (DTTOs). The arrival of this sentencing "tool" coincided with the launch of the Pilot Glasgow Drugs Court. The evaluation of these, which were being piloted in Glasgow, was published in October 2002. Weekly expenditure on drugs had gone down from $£ 490$ to $£ 57$ after six months. There was also some evidence of a reduction in drug related crime in Glasgow. The cost of one DTTO was estimated at $£ 7,992$. This is replicated by the finding of evaluators of

39 See the executive summary of the First Six Months pp i-iv. 
DTTOs in England and Wales. ${ }^{40}$ There is little doubt that the measures competed with each other. I come back to this issue in my conclusions.

There has to be an additional caveat. It is impossible, or at the very least difficult, not to be impressed by the sincerity, dedication and altruism of all those types of professionals involved in Drugs Court schemes. This applied in Paramatta, Glasgow and in Dublin. Perhaps a good indication of this was on the occasion of the first "graduation" from the Dublin pilot court held at the Richmond Centre, appropriately a former converted hospital. The "psycho-drama" of hearing two former drug addicts address the court in the presence of a Supreme Court Judge, Mrs Justice Denham, and the presiding District judge, Judge Haughton, was, quite simply, very moving. It so moved members of the press and media who made up a sizeable part of the audience that they joined in the applause, along with relatives, court personnel and other participants in the Drug Court scheme.

This is described as one of the central and beneficial aspects of the ethos of Drugs Courts but the "feel good factor" can be capable of misleading. Everyone wants the scheme and the individual to succeed. Even professional evaluators cannot be regarded as totally immune to this feeling especially when there must be so many ways of assessing outcomes. Improvements in health and in life styles are difficult, though not impossible, to quantify. Recidivism is capable of being statistically measured but that takes time. Perhaps the one thing that is most easily capable of assessment is the cost of resources and of time upon which figures can be put. Improvements in procedures, in processing, the benefit to court and health clinicians' time are also quantifiable.

Outcome results however take time. It is only right that a broader view than that based on mere rates of recidivism be taken. If improvements to an individual's health and in his life style are factored in then, there are going to be consequential benefits to health, education and to public expenditure. The trouble is that everyone involved wants this to work and few start from either a sceptical or neutral viewpoint. That has to be borne in mind when assessing evaluations and their methodology.

The conclusions of the evaluators in October 2002 were:

"The formative and process evaluation of the first six months of the pilot Drugs Court in action suggest that the initiative has largely been a success, with the role of the Drugs Court Sheriffs having been critical in this respect. Certain issues have been identified that will require particular attention in the next phase of the pilot. These include the police contribution to the referral process, the multi-disciplinary team-working, the workload of different professionals involved in the operation of the Drugs Court and the availability of a wider range of sanctions and rewards for, respectively, noncompliance and progress. Overall, however, the Glasgow Drug Court was perceived to be very effective in providing a resource for drug using offenders. The dedicated team and

40 Drug Treatment and Testing Orders: Final Evaluation report, Home Office Research Study 212 October 2000, pp vii-viii. 
resources were viewed as a positive contribution to the reduction of drug-related offences in Glasgow."41

\section{The Dublin Pilot Court at the Richmond Courthouse}

The Republic of Ireland's Working Group on a Court commission was requested by the Minister for Justice, Equality and Law Reform, John O'Donoghue,TD, to advise on the establishment of a Drugs Court system in 1997. This was against a background of both a serious hard drug problem in Dublin and an established link between drug abuse and other crime. ${ }^{42}$
"19,046 indictable crimes were detected in the Dublin
Metropolitan area during the time under review. 7,757
individuals were apprehended for these crimes. Of the individual offenders apprehended 3,365 or $43 \%$ were identified as known hard drug users. These drug users were responsible for 12,583 crimes or $66 \%$ of all detected crime in the Dublin Metropolitan Area. Based on detections, drug users commit approximately three crimes for each one committed by non drug users." 43

In short the Working Group considered a Drug Court and how such a scheme could be fitted into existing legislative arrangements. It also surveyed existing health resources in both the public and voluntary sector including those available to the Probation service. It recommended the setting up of a Drugs Court Planning Committee, the appointment of a Drugs Court coordinator and the establishment of a Drugs Court concentrating on opiate abusing offenders. Whilst it envisaged the use of existing legislation it recommended the provision by statute of a new Drugs Court order. It also suggested a period of three years for the scheme to be assessed. ${ }^{44}$

The Drugs Court Planning Committee reported in August 1999.45 Its brief was to establish and monitor a pilot Drug Court programme. It considered available resources and procedural matters and set a target date of early 2000 for the court to be up and running, selecting Dublin's North Inner city as the catchment area.

The Court actually opened its doors on $9^{\text {th }}$ January 2001, the understandable delay being due to a concern to have all the necessary resources in place. The catchment area was the North Inner City of Dublin and the pilot was to initially run for 18 months. It would take those over 17 years of age who both consented and pleaded guilty. After acceptance by the Court the

41 The First Six Months, p v.

42 The Eastern Health Board estimated that there were approximately 10,000 heroin users in the Dublin area. I assume this to mean "problem users". It is a high number. The estimate made by Karen McElrath was of 1,000 in Northern Ireland see NIO Research 2002.

43 Illicit Dug Use and Related Criminal Activity, Eamon Keogh, Garda Reserch Unit, Dublin 1997.

44 Report of the Working Group on a Court Commission, Drugs Courts, February 1998, Dublin.

45 First report of the Drug Court planning Committee, August 1999. While the membership of the Committee was largely criminal justice - based at least six members came from heath and areas outside criminal justice. 
requirements of attendance at court were incorporated in a bail bond, which provided for the suspension of bail for up to eight days in the event of failure to comply with either the conditions of bail or the requirements of the Drug Court treatment programme. Unlike the Glasgow Pilot there was, inbuilt to the scheme, this power to impose immediate sanctions of a custodial nature.

The framework of pre-court review meetings at which the participant's progress would be discussed, in his /her absence, by a multi-disciplinary team headed by a district judge, followed by a court review at which the offender was present is similar to Parramatta and Glasgow. There were, unlike in Glasgow, different formal stages with eventual graduation. Drug testing was frequent with requirements initially of tests $2 / 3$ times a week coming down to once a week. Substitute prescribing was, once again, one of the core treatment regimes. The participant had access to both a wide range of health-based resources and also to a considerable range of other professional help and advice. Finally, the existence of the Probation Act 1908 proved extremely useful as it empowered the court to "extend the benefit" of the Act and enabled it to make an Order without that counting as a conviction.

There was a slow start. While it was envisaged that the pilot could accommodate up to 100 participants at a time referrals to the court were slow in coming. There are no doubt many reasons for this. One clearly was a judicial reluctance to transfer cases that had come before their court. Another difficulty may have been lack of knowledge about what was available. It may also be the case that the incentives to a prospective participant of "getting better" did not appear to outweigh the rigours of a commitment to what must appear to be a demanding regime. The consequences of failure along the way are perhaps not drastic but the potential deprivation of liberty is flagged up at the very start.

The first graduation day was on $5^{\text {th }}$ December 2002 with two graduates. It was anticipated that there might be three but the case review of the third was told that morning of a relapse which had occurred after a period of abstinence of 18 months. The court had a difficult decision to make but it had really little option. It deferred "graduation" in respect of a person who had otherwise worked very hard. It was almost as if there had been "selfsabotage" but one of the difficulties facing any court and health worker in this field is the clear potential for relapse at any stage.

Of the two who did graduate that day one entered the court programme on $10^{\text {th }}$ July 2001; he completed phase one in September 2001 and phase two in May 2002. His personal history, criminal record and drugs history was not untypical. Alcohol abuse began at age 12 and progressed to abuse of other drugs at 17 with abuse of heroin coming later. His criminal history started in 1995 and, whilst it included a substantial suspended sentence, only 30 days actual imprisonment had been imposed in the past. This record was mirrored by his drug abuse with residential drug treatment in 1995, relapse two years later and a methadone reduction course in 1998, relapse in 1999 to abuse of heroin and then the committal of the offences for which he entered the Drugs Court programme in 2001. Of course it is impossible to predict the eventual outcome, especially given the history of relapses, but it seemed very clear, whatever way it was looked at, (improvement in health, lifestyle, the consumption of drugs and the reduction of offending) that the programme 
had achieved a marked success over its period. When comparing the cost of prison with the cost of the programme, this, looked at purely from accountancy terms, would seem to be cost effective. There is some provision for follow up with post graduation meetings and support groups if these are felt helpful.

When looking at these three courts one of the outstanding factors in each is the extent of resources available to the court. In Dublin this, understandably, reflects the high political priority given to an acute problem. Equally, the pace of health development has also reflected this. The three years up to 1999 saw treatment places there rise by 2,500 and treatment locations rise from 34-53. In 199937 new stabilisation beds were provided and the increase in treatment centres was 21 .

As the Dublin pilot moves from its pilot status to being rolled out, it still remains unclear how effective the Court is. It is early to assess eventual outcomes both because of the short periods involved and also the low numbers coming through. How one measures outcomes, benefits to the individual and benefits to the community, how control groups are decided and the timescale within which that measurement is to be done are all matters which are going to be important. The issue of greatest importance however is the political priority given to the problem. So long as the problem of opiate drug abuse remains acute in Dublin one suspects that the resources and priorities will favour the Drugs Court scheme.

\section{The Northern Ireland Position}

I approach this with some caution. Heroin as a significant drug of abuse has been a fairly recent development on the illicit drug scene in Northern Ireland. Partly as a result of this and partly because of the shortage of resources allocated to addiction research inside a small jurisdiction formal statistical research is very limited. The advent in 2000 of the Northern Ireland Drug Misuse Database Register ${ }^{46}$ has been of help but its effect on available statistics has yet to be fully felt. Actual studies or projects, be they health or criminal justice inspired, have been limited. The Northern Ireland Drug Addicts Index whereby Doctors are required to notify certain addictions is still maintained. ${ }^{47}$

The picture, as perceived by the Drugs Squad of the former Royal Ulster Constabulary, was, at the end of 1999 , that opiate abuse was both of recent origin and largely centred on Ballymena. ${ }^{48}$ The latter half of 1997 saw a significant rise in the Ballymena area of numbers abusing heroin. In the same period, according to the police, the method of abuse of heroin altered from smoking or chasing to syringe and injecting. ${ }^{49}$ If the police view is

46 The Northern Ireland Drugs Misuse Database April 2000. DHSSPS.

47 NI Drug Addicts Index 2003, published February 2004. It records 241 notified addicts, $72 \%$ of whom principally abuse heroin.

48 Provided by the RUC Drugs Squad, 1999.

49 For a fascinating account of both the different types of heroin (Medical morphine, brown and white heroin) and of means of use of heroin (Injecting, snorting and smoking or chasing), and of the medical and health implications of the same see, Prevalence of Heroin Use In N.I., Karen McElrath, DHSSPS, May 2002. 
accepted there were between 300 and 400 persons abusing heroin in the Ballymena area, compared to 200 in $1997 .^{50}$

The relationship between heroin abuse and other types of crime mirrors that experienced in Sydney. ${ }^{51}$ An analysis carried out by the RUC of police files showed that of a total of 65 robberies carried out in the Ballymena area between July 1998 and March 199939 were heroin related. Whilst robberies figures had shown some increase in the years immediately preceding 1997 , they jumped from 40 to 62 between 1997 and 1998.

Not only was there some local support for a connection between heroin dependency and crimes of robbery in Ballymena there was also local police belief that there was a connection between acquisitive crimes generally and the opiate problem in Ballymena. There has now been some limited support for this view. In a study carried out by the police analysis branch ${ }^{52}$ the following emerged. During the period from 26 November to 6 January $(6$ weeks) 43 persons were arrested for acquisitive crime of which 20 were heroin users. Of the 113 crimes cleared 86 were heroin related. There was some difference between burglary and theft/deception offences where the heroin user percentages were $64 \%$ and $76 \%$. This overall connection is not surprising and reflects the view of the police that many of the "victims" of dealers are in the lower socio-economic bracket and unable to afford purchases of heroin without resort to crime. Whether it is the intention of dealers to ensure their clients remained as customers (police view) or whether it shows an easier flow of certain types of heroin into Northern Ireland, the price of a "wrap" had reduced significantly in 1999.

It was the police view that they faced difficulties penetrating the heroin trade in Northern Ireland and that without coordinated action by others such as health, education and housing it would be impossible to counter the increase in opiate trade in Northern Ireland.

The Probation Service of Northern Ireland has initiated research into the suspected connection between drug misuse and crime. A study of 436 Presentence Reports for 2001 found that drug misuse was related to the current offence in $13 \%$ of cases. Alcohol was implicated in $45 \%$ of cases. The figure for past offences was $10 \%$ and $40 \%$ respectively. ${ }^{53}$ Similarly, in a survey of substance abuse among 293 prisoners in Maghaberry Prison some

50 It is possible that the apparent coincidence of this increases with the ceasefire and the aftermath of the Hillsborough Agreement is not entirely accidental. A hypothesis put forward by the former RUC is that certain individuals who had been expelled from Ballymena for selling other drugs returned as heroin addicts from places in England. They brought with them their own sources of supply. There has been a spread of the problem of abuse of heroin by injecting to other areas in Northern Ireland but the epicentre still seems to be Ballymena. Although it can understandably be dramatised by the media ("Addict toll rising in capital of heroin misuse, N.I." The Irish News 17 February, 2000) Ballymena seems to remain a centre of supply and distribution of the drug.

51 In England see Hayton, 1998, A Study Of The Drug Scene In Plymouth. Plymouth and Devon Health Authority has an innovative policy running since 1997 based on harm reduction, methadone prescribing and involving both probation and police. See also Police Research Group, Home Office 1998.

52 Acquisitive Crime and Heroin Misuse. Neeson, Police Analysis Branch, 2002.

53 Information source PBNI. 
$30 \%$ of remand and $16 \%$ of sentenced prisoners reported drug misuse prior to imprisonment. ${ }^{54}$

Hospital statistics show a rise in numbers attending health facilities for treatment in connection with drugs (largely heroin). There was a tenfold increase between 1995 and 1998 to 102 persons. ${ }^{55}$ A study conducted in Ballymena in 2000 estimated that in 1999-2000 there were 235-398 "heroin users" in the Homefirst Trust, which covers the Ballymena area. ${ }^{56}$ Amongst this plethora of confusing statistics the 2003 figures from the Northern Ireland Drug Abuse Database do not record an appreciable increase in those presenting for treatment for heroin. Indeed the percentage reporting heroin abuse had reduced to $15 \%$ from $21 \%$ in 2001 . Injecting behaviour had also significantly reduced. ${ }^{57}$ Ballymena still had a figure approaching half of those in Northern Ireland abusing heroin.

Not much can be gleaned from the prosecution statistics kept by the office of the Director of Public Prosecutions. Court disposals in all courts of all types of offenders for drug offences were, in 1995, a total of 671 and, in 1999, a total of 581. These declines probably result from different policies by the police and prosecution as to how they deal with drug offences. The approach adopted by the courts had also perhaps ameliorated. Of the disposals made in 1995, $18 \%$ were sentenced to immediate custody and of those in 1999, $15 \%$ were immediately sentenced to custody. Great care has to be used in making any such conclusions however. Not only could there be changes in prosecution policy but there could also be alterations in the numbers of certain types of drugs coming before the courts. The reclassification of cannabis in February 2004 has still to have impact but, given the increase in penalties for trafficking in Class $\mathrm{C}$ drugs, that impact will be somewhat muted.

On this information, the picture in Northern Ireland and, locally, in the Division of Antrim would be less than clear. There has however been a recent comprehensive study ${ }^{58}$ funded by the Drug and Alcohol Information and Research Unit of the Department of Health and Social and Public Safety. Its purpose was to provide estimates of the numbers of problem heroin users in Northern Ireland. ${ }^{59}$ It estimated there to be between 695 and 1250 addicts

54 Campbell et al. Survey of Drug Misuse amongst Prisoners in HMP Maghaberry, PBNI, 2002. The figures for "self-reporting" of drug use by prisoners inside prison make interesting reading.

55 The local police view is that this rise masks the true extent of the problem since many addicts seek to conceal their addiction from family General Practitioners. I am not sure if current practice has changed but a referral to a community addiction team had to made by first seeing the patient's own GP. It was also then the view of the police that the only local facility for residential treatment and detoxification was at Holywell Hospital, Antrim, which had a reputation as a mental institution. Addicts do not see their problem as a mental illness.

56 Woodhouse et al Heroin Needs Assessment. Ballymena; Homefirst Community Addiction Service, 2000.

57 Statistics from the Northern Ireland Drug Misuse Database, October 2003, at p 9.

58 Prevalence of Heroin Misuse in Northern Ireland op cit.

59 Using the BMA definition of “. . . use resulting in social, psychological, physical or legal problems associated with dependence, intoxication or regular 
in the period between 1 November 2000 and 31 October 2001, with the higher part of the range reflecting a group of users who, although not dependent on heroin, are using opiates in a sufficiently intense or risky fashion to be at significant risk of serious health or social consequences. ${ }^{60}$ The treatment data suggested that Ballymena had a higher proportion of injecting users and of younger users than elsewhere. ${ }^{61}$

There are of course uncertainties. Are users who smoke and snort heroin likely to progress to injecting? Are users more likely to go to treatment centres in Ballymena more quickly than elsewhere in Northern Ireland or, alternatively, is there a very large group of heroin users in that community who have not yet progressed to the sort of problematic use that would be identified in the data the report examined: treatment services, the addicts index ${ }^{62}$ and arrests? The answer to this is of some importance. Resources are scarce and will be targeted at where there are perceived to be areas of need. ${ }^{63}$

It will be on estimates of projected figures that "treatment opportunities" such as residential accommodation, outpatient facilities and substitute prescription will depend. The figures locally are a matter of concern but they do not suggest a problem on the scale of any of the cities studied. The problem really is to assess what is happening.

Presently the response by government has been increasing. There is a Northern Ireland Drug Strategy. ${ }^{64}$ A coordinator has been appointed to oversee the Government's approach to illicit drugs. Rob Phibbs replaced the first coordinator, Jo Daykin, in 2003. A wide range of working parties have been set up covering all those disciplines that could be relevant to drugs. They both bring together Departments and those from outside Government who have an interest in the subject of drug abuse and treatment. Currently substitute prescribing has been made available and is in the process of being provided across the various Health Boards. This is a recent but a major development for Northern Ireland and its implications will be considerable. They will also take time to assess.

One of the working parties is the Criminal Justice Working Party on Drugs. In the short term, the Government has made some funds available in excess of budgeted expenditure for purposes that are within the remit covered by

${ }^{60} \mathrm{p} 34$

consumption". Its methodology was to essentially use three different measures of input based on the treatment services, the addicts register and arrests.

61 Figures suggested that persons treated in Ballymena were 12 times more likely than those treated in Belfast to have injected. Interestingly there were in this period 21 deaths with heroin listed as the main cause. Average age of the deceased was 36. This compares with Dublin where in 199523 deaths were recorded in an area with a much larger number of addicts. One wonders whether this is because of differences in treatment regimes, a question posed by the author of the Report at p 32.

62 The NI Drugs Misuse Database established in April 2000.

63 In the Wirral, according to a report quoted at p 38, there were believed to be relatively few heroin users resident in the early 1980s but this had, within six years, grown to approximately 4000 .

64 Published in August 1999, NIO. 
this committee. These funds, however, are for projects that are essentially time limited. The interesting aspect of the work of this group is that it is the first obvious example of those concerned with health and welfare working together with those concerned with criminal justice. For understandable reasons I confine my remarks to criminal justice measures.

The following is very much a snap shot of what is happening and, since that relates to illicit drugs generally, there is not much that is specifically geared to the problem of opiates.

The principal powers that sentencers possess in Northern Ireland and which can incorporate a "therapeutic" element include probation orders to which a "condition of treatment" can be added ${ }^{65}$ and the interesting innovation of custody/probation orders to which such a condition can also be added. Some sentencers have also used informally the power of adjourning a case to allow treatment to begin. More formally, but without any power to impose conditions, courts have used the power to defer sentence for up to six months to allow such treatment to begin or take place. A suggestion that the limitation of the period of deferral be extended to 12 months was initially well received by Government. The period of six months is too short to allow detoxification, assessment, placement on a course of treatment and then realistic assessment of progress to be made. For cases of addiction to hard drugs, deferral with its facility for immediate return to court has very considerable advantages. The proposal has, so far, not been taken up.

But what treatment is available, both for drug dependency generally and opiate dependency in particular?

A common theme coming from criminal justice has been both the lack of treatment facilities and the absence of certain treatment regimes, particularly in relation to the treatment of opiate abusing offenders. It is the view of Oliver Brannigan, the former Chief Executive of the Probation Service for Northern Ireland that there is a gap in the provision of a residential treatment facility dedicated to the detoxification and treatment of those coming off hard drugs. It is his view that whilst limited short term detoxification facilities exist in hospitals in Northern Ireland, "these are not positive environments for reforming addicts to rebuild their lives in a safe context with the help of a constructive regime and therapeutic interventions."

The former head of the Drug Squad of the RUC puts it even more strongly. It is his view that the requirement that addicts seeking treatment from community addiction teams be referred by their GPs and the fact that the only facilities for detoxification exist in a local hospital whose history is well known locally as that of a mental institution means that many opiate addicts are reluctant to refer themselves for treatment. These are views that have been put to the local health authorities and by the police to the former security minister, Adam Ingram.

\section{CONCLUSIONS.}

I trust these conclusions are realistic rather than complacent. In part they reflect uncertainty about the extent of the opiate problem in Northern Ireland.

65 Criminal Justice Order (NI) 1966. 
On the other hand there is little doubt about the close connection of that problem with acquisitive and violent crime. They also reflect the current position that Northern Ireland has reached as regards both treatment regimes and facilities. It will take some time before the impact of substitute prescribing is absorbed. Treatment facilities will always be limited. The conclusions however also reflect my own personal uncertainties about the extent to which the concept of a Drugs Court can usefully be applied to our local conditions in Northern Ireland.

If there appears to be significant benefit to the safety of the public and also to the health of individuals then the case for commencing a Drugs Court becomes considerable. The stage where that benefit can be clearly demonstrated has not yet arrived but may do so. There would be no point however in starting such a Court without the clearest indication that it is merited in terms of the problem and also that the treatment regimes and facilities exist which it needs. There is significant under-provision of residential and community care in Northern Ireland in this area.

I have therefore attempted to suggest a set of proposals that I feel are realistic.

The first is that the statistical efforts started by the Northern Ireland Office and the Department of Heath, Social Services and Public Safety continue. We really need to know the extent of the problem. I repeat the recommendation by Karen McElrath that there should be additional research with heroin users in Northern Ireland who are not in contact with health services. ${ }^{66}$ This should be undertaken with urgency.

The second is that consideration should now be given to the introduction here of Drug Treatment and Testing Orders. There is evidence that these have been to some extent beneficial in England and Wales and now in Scotland. ${ }^{67}$ Whilst a mixed picture may have emerged of differences in regional implementation of these there is no doubt that they are capable of having an impact on drug related crime. ${ }^{68}$ The power to bring in such Orders was contained in the Criminal Justice (NI) Order $1998 .{ }^{69}$ But it was never activated. This in itself will have substantial resource implications and make demands for health and criminal justice to work together in ways that are novel to Northern Ireland.

66 Prevalence of Heroin Abuse in N.I. op cit.

67 DTTOs Final Evaluation Report Home Office 2000.

68 National Audit Office: DTTOs, Early Lessons, London, HMSO March 2004. This report presents a very mixed picture. The success rate, if one calls it that, of successful completion of Orders is $28 \%$. However, of those $50 \%$ appear to have stopped offending. When one considers the relationship between abuse of opiates and acquisitive crime this is a significant figure. There is no doubt a lesson to be learnt from this about better selection, earlier termination/breaching and of essentially a better targeting of resources and monitoring of outcomes. The cost per day is significantly less than the daily cost of imprisonment and, if early indications are right about reduced offending rates amongst those who successfully complete orders, then this is both cost effective and effective in reducing drug consumption and associated crime.

69 Art 8 
The third is that consideration should be given to extending the period for deferral from 6 months to one year. The Scottish system has a much wider power to defer and it has proved very useful. ${ }^{70}$ In my view it would allow closer supervision of offenders subject to a drug addiction. Whilst I would not envisage it being used in many cases the benefits of having an immediate return to court for sentence if expectations are disappointed are self-evident.

Finally, there should be a comparative study both of the ongoing and past evaluations of the Drug Courts at Glasgow, Dublin and Parramatta. This study should be geared to assessing the benefit to Northern Ireland of the introduction of a similar scheme here. I do not intend to minimise the difficulties of this in any way and I hope I have pointed out some of these above. The benefits of such a scheme would, if successful, be considerable. I have no desire to widen the net of those who ultimately go to prison and, as an American judge put it, there is no worse breach of the concept of the separation of powers than an unrestrained judiciary full of amateur psychologists, but if the figures show there to be a benefit to public safety and to health then the concept merits further investigation

I am finalising these conclusions after adjourning a case for a pre-sentence report of a 19 year old unemployed heroin addict who told me he paid his dealers $£ 50$ a day. It is not surprising perhaps that he spent six months of last year in custody at the Young Offenders Centre. The offences he admitted in the course of 2003 included thefts, burglaries and criminal damage. Taken altogether they totalled 12 but another 41 were "taken into consideration" by the Magistrate who dealt with him last. One does not have to be good at multiplication to assess the impact on public safety of this record. Is it too simplistic to say that dealing with the addiction of this offender will be of benefit to the public?

70 Deferral Of Sentence in Scotland, Scottish Office 1998. 